\title{
Corporate Diversification and Financial Performance: A Review of Literature
}

\author{
Meysam Doaei (Corresponding Author) \\ Faculty of Management and Human Resource Development \\ Universiti Teknologi Malaysia, Skudai, Johor Bahro, Malaysia \\ E-mail: dmeysam2@live.utm.my
}

Dr. Melati B. Ahmad Anuar

Faculty of Management and Human Resource Development Universiti Teknologi Malaysia, Skudai, Johor Bahro, Malaysia E-mail: m-melati@utm.my

Dr. Nik Intan Norhan Adb Hamid

Faculty of Management and Human Resource Development Universiti Teknologi Malaysia, Skudai, Johor Bahro, Malaysia E-mail: m-norhan@utm.my

Received: May 13, 2012 Accepted: June 28, 2012 Published: December 1, 2012 doi:10.5296/ajfa.v4i2.1786 URL: http://dx.doi.org/10.5296/ajfa.v4i2.1786

\begin{abstract}
The impact of corporate diversification on financial performance has been subject of some studies from the past. In addition, scholars found positive or negative relationship between the two variables. However, there are some theories and motivation which explain the part of relationship that state in this paper. In this paper, we try to show measurement of diversification and summary of related studies.
\end{abstract}

Keywords: Product diversification, International diversification, Financial performance 


\section{Introduction}

The corporate diversification and financial performance has been subject of many studies in finance in last three decades (Y. S. Kim \& Mathur, 2008; Santalo \& Becerra, 2008). The paper discusses this issues base on the definitions, measurement and results of related research.

\section{Definitions}

There are many definitions of corporate diversification. However, diversification word comes from the diverse, which means distinct and different that shows a discrepancy in the firm activities (R. Pitts \& Hopkins, 1982). When a firm operates in more than one business or industries, it is called the diversified firm (Barney, 2010; M. Hitt \& Ireland, 1986; Ibrahim \& Kaka, 2007; Santalo \& Becerra, 2008). Furthermore, diversification means increased activity of their business scopes except their currently business (Hillebrandt \& Cannon, 1990). Other scholars defined diversification as firm enters new sector (Iacobucci \& R'osa, 2005), or new industry (Jacquemin \& Berry, 1979), or new segment (Denis, Denis, \& Sarin, 1999) or a new line of businesse (C. Montgomery, 1994).

Moreover, according to Ansoff (1957), corporate diversification classified into two groups, product diversification and international (geographic) diversification. Product diversification means a firm produces more than one kind of product and international diversification means a firm acts in abroad markets (M. A. Hitt, Ireland, \& Hoskisson, 2007).

\section{Corporate Diversification Dimensions}

Ansoff (1957) defined corporate diversification as product diversification (related and unrelated) and international diversification. Also, product diversification can be divided into three dimensions, which are diversification degree, diversification type and diversification mode (Datta, Rajagopalan, \& Rasheed, 1991).

\section{Diversification degree}

It introduced through three main methods of computing based on the business count measurement which are: Standard Industrial Classification (SIC) codes, Herfindahl index and Entropy index. In addition, there is no agreement of which measurement is the best one for determining corporate diversification (Shackman, 2007).

SIC codes are a system for identifying a business according to its activity, which is the easiest way for counting diversification and Martin and Sayrak (2003) noted that there is a problem for using the SIC codes. They expressed if a firm operates in many industries, SIC codes cannot explain which industry is more important than others for the firm. For solving this problem, it is suggested to use Herfindahl index, which was introduced for firm's concentration counting (Berry, 1971; McConnell, Brue, \& Flynn, 2009; McVey, 1972).

Herfindahl Index is defined as the total square of the sales share of each product of the firm as noted in Equation 2.1: 
Equation 2.1: Herfindahl Index

$$
\mathrm{H}=\sum_{i=1}^{n} \mathrm{P}_{\mathrm{i}}^{2} \quad ; 0<H \leq 1
$$

Where, $P_{i}$ is the sales share of product $i$ in the firm in terms of percentage and $n$ is the number of product units of the firm. When this index is near zero, it means that the firm is diversified. The high Herfindahl index is, the more focus the firm is (Berry, 1971; McVey, 1972). This index also is known as Herfindahl-Hirschmann index.

The last measurement is Entropy Index which was proposed primarily in physics; however, it spread into other subjects. Jacquemin and Berry (1979) extended entropy index in diversification researches. The index has three significant elements, which are different from other indexes. The elements are the number of industry of firm's activities, the amount of total sales/assets divide across industry parts, and the third is that power of part of unrelated and related diversification in a firm (Amit \& Livnat, 1988; Baysinger \& Hoskisson, 1989; Palepu, 1985). Park and Jang (2011) said the index is objective, continues and decomposable. In addition, Chatterjee and Blocher (1992) reported the entropy index for diversification is better than other diversification measurements. Therefore, these privileges cause the wide range of using entropy index (C. J. Chen \& Yu, 2011; Park \& Jang, 2011). The total entropy index is measures as Equation 2.2:

\section{Equation 2.1: Total Entropy Index}

$$
\mathrm{E}=\sum_{i=1}^{n} \mathrm{P}_{\mathrm{i}} \ln \left(1 / \mathrm{P}_{\mathrm{i}}\right)
$$

Where, $P_{i}$ is the share sale of segment $i$ in total sales of the firm and $n$ is the number of firm's segments

As it mentioned, the main privilege of entropy index is that it can determine the score of related and unrelated diversification in the firm (refer to (Jacquemin \& Berry, 1979)). In addition, if total entropy is near zero, it means that firm is focus and becomes greater with increasing levels of diversification, and the maximum and minimum of Entropy is $0 \leq \mathrm{E} \leq$ $\ln n$.

\section{Diversification Type}

Wringley (1970) defined diversification type based on relatedness within the firm's portfolio in four majors which are single, dominant, related and unrelated diversification. Rumelt (1974) extended these four parts into seven parts, which are single dominant, dominant vertical, dominant constrained, dominant linked-unrelated, related constrained, related linked and unrelated business. However, he said sometimes it is difficult to count these ratios because of the firm's uncomplete reports. In addition, he stated that related diversification could transfer core skill to new businesses; however, unrelated diversification could not. Aditionally, some scholars used another classification with mix Wringley and Rumelt's ideas 
together which are single, moderately diversified and highly diversified (Li, 2004; Pandya \& Rao, 1998).

\section{Diversification Mode}

Scholars define mode of diversification as internal development and merger and acquisition (NA Berg, 1973; Lamont \& Anderson, 1985; R. Pitts, 1976; R. A. Pitts, 1977; Yip, 1982). Internal development takes advantage of interior resources and core competency for establishing a new business (Datta, et al., 1991). In contrast, if a firm likes to diversify via merger and acquisition, it must pay attention to the weaknesses and strengths of a target firm (N. Berg \& Pitts, 1979).

\section{International Diversification}

International diversification means a firm acts in the market which is not in its country (M. A. Hitt, et al., 2007). This strategy is a growth strategy that has a major effect on firm performance (Capar \& Kotabe, 2003). This effect is stated by Ansoff (1965) as growth strategy.

As a matter of fact, international diversification offers several advantages to firms. Buhner (1987) argued that international diversification offers prospective market opportunities, which gives firms the opportunity for greater growth. The most accepted argument for international diversification has been developed on the theoretical assumption that firms exploit the benefits of internalization in international markets (Caves, 2007; Hymer, 1976). Internalization of markets has advantages such as economies of scale, scope, and learning (Ghoshal, 1987; W. Kim, Hwang, \& Burgers, 1989; W. C. Kim, Hwang, \& Burgers, 1993; Kogut, 1993), and sharing core competencies among different business segments and geographic markets (Hamel, 1991).

Firms with strong competencies that are developed at home can utilize these in international markets (Bartlett \& Ghoshal, 1999). Thus it is argued that the higher the involvement of a firm in international markets is, the higher will be the exploitation of tangible and intangible resources, which is expected to lead to higher performance (Hymer, 1976).

In addition, multinational firms have the opportunity to integrate their activities across borders by standardizing products, rationalizing production, and/or allocating their resources more efficiently and effectively (Kobrin, 1991). Furthermore, multinational firms can gain additional competitive advantages by exploiting market imperfections (such as a less competitive environment) and cross-border transactions (such as transfer pricing), and can also achieve a greater bargaining power with increased size (Sundaram \& Black, 1992). All of these arguments support the view that a positive, linear relationship exists between international diversity and performance. Although some studies have demonstrated a positive relationship (Daniels \& Bracker, 1989; Gomes \& Ramaswamy, 1999; Grant, 1987; Haar, 1989), other studies have shown either a negative relationship or no relationship at all (Siddharthan \& Lall, 1982). Most of these studies have assumed that the relationship between international diversification and performance is linear (Gomes \& Ramaswamy, 1999). 
However, some of research has examined a nonlinear relationship between multinationality and performance, and has argued for a theoretical rationale to justify their position (Gomes \& Ramaswamy, 1999; M. A. Hitt, Hoskisson, \& Kim, 1997; Kotabe, Srinivasan, \& Aulakh, 2002; Tallman \& Li, 1996). These studies have found an inverse U-shaped relationship between multinationality and firm performance, where performance increases up to a certain point, and then levels off.

Table 1. International Diversification Measures

\begin{tabular}{|l|l|l|}
\hline Authors & Method & Symbol \\
\hline Geringer et al (2000) & foreign sales/total sales & FSTS \\
\hline Fatemi (1984) & foreign assets/total assets & FATA \\
\hline Kohers (1975) & $\begin{array}{l}\text { number of foreign employees/total number of } \\
\text { employees }\end{array}$ & FETN \\
\hline Vernon (1971) & foreign earnings/total earnings & FETE \\
\hline Geyikadgi and Geyikadgi (1989) & foreign business/total business & FBTB \\
\hline Contractor et al. (2003) & $\begin{array}{l}\text { number of foreign offices/total number of } \\
\text { offices }\end{array}$ & FOTO \\
\hline Miller and Pras (1980) & $\begin{array}{l}\text { number of nations in which firm has foreign } \\
\text { subsidiaries }\end{array}$ & NNS \\
\hline Morck and Yeung (1991) & number of subsidiaries abroad & NFS \\
\hline Kim and Lyn (1987) & foreign direct investment & FDI \\
\hline Errunza and Senbet (1984) & absolute foreign sales & AFS \\
\hline
\end{tabular}

The other significant subject is that the measurement of international diversification. For computing international diversification there are several methods as discussed in Table . However, most of related researches have used foreign sales/total sales for measure international diversification (Bobillo, López-Iturriaga, \& Tejerina-Gaite, 2010; Capar \& Kotabe, 2003; Geringer, et al., 2000; Grant, 1987; Habib \& Victor, 1991; Sullivan, 1994a, 1994b; Tallman \& Li, 1996).

\section{The Theory of Why Firm Diversify}

The main theories about why firm diversify, are as agency theory, free cash flow theory, efficiency theory, resource based theory and market power theory.

Agency Theory: Jensen and Meckling (1976) define that the conflict between owner (principal) and manager (agent) of the firm. In addition, the theory states that diversification is driven by managers' interests such as employment risk-reduction, power, prestige and high compensation (Ahmad, Ishak, \& Manaf, 2003). Whilst, shareholders can diversify their portfolios at low cost to balance their investment risk and therefore they might not favor corporate diversification strategies. Due to the nature of corporate structure, shareholders might be forced to accept the firms' diversification strategy although it might not suit their risk and return profiles. Hence, agency theory would predict a negative relationship between diversification and firm value.

Free Cash Flow Theory: the theory is explained by Jensen (1986) that anticipate which type 
of diversification create or destroy value. Managers can spend free cash flow (FCF) in profitable investment opportunities or paying out to shareholders. So, the theory states managers with unused borrowing power and large FCF are more probable to undertake low-benefit or even value-destroying mergers.

Efficiency Theory: the efficiency theory suggests that diversification occurs once managers are expected to make some synergies (Mat Nor, 2003). These synergies are such as financial synergy (unrelated diversification) and operational synergy (related diversification).

Resource based Theory: Penrose (1959) developed resource based theory which states every firm has remarkable resources that are known as its competitive advantages and firm can use some unused capacities by applying diversification strategy. This view implies that a firm can be more profitable where applying the unused resources (C. Montgomery, 1994) where these resources of firm has differences in specificity (C. A. Montgomery \& Wernerfelt, 1988).

Market Power Theory: this theory stemmed from a fear of market being monopolized (C. Montgomery, 1994). Because, diversified firms act in many geographic market and produce many products so its market power increases (Edwards, 1955). Furthermore, when a firm diversifies related diversification, it increases the market power. By having market power, it can stabilize the position and use predatory pricing to improve its profitability. Researchers hypothesized that diversification increases market power; then, more profit can gain for the diversified firm (Caves, 1981; R. A. Miller, 1973).

\section{Previous Studies}

In this section, some significant researches from developed and developing countries are discussed based on their variables and findings. In addition, at the end of the each part a table of summary is presented.

\section{Studies on Developed Countries}

The diversification and performance study has started from USA. One of the first authors on this area was Rumelt. Rumelt $(1974 ;$ 1982) noted that related diversification makes more profit than unrelated diversification, because firms in related form can transfer core competencies.

Caper and Kotabe (2003) examined the relationship between international diversification and firm performance in service firms in sample of 81 major German service firms across four industries. They found out that there was a curvilinear relationship between multinationality and performance in German service firms.

Jung and Chan-Olmsted (2005) found a positive relation between related product and international diversification and financial performance among media firms in United States. In addition, they concluded the more related product and international diversification, the more financial performance.

Brammer et al. (2006) investigated between corporate social performance and geographical diversification on a sample of large UK firms. They found out evidence of a significant 
positive relationship between the two for some types of social performance and in some regions of the world. However, they shown that the relationship between geographical diversification and social performance differs significantly across different components of social performance.

Qian et al. (2008) examined on largest US firms during the years 1996-2000 that how regional (international) diversification affects firm performance. They controlled size, age, leverage, risk, R\&D intensity, product scope, and industry effect. The results indicated that regional diversification has linear and curvilinear effects on firm performance. Regional diversification enhances firm performance linearly up to a certain threshold, and then its impact becomes negative. The results also showed that firms of developed countries maximize their performance when they operate across a moderate number of developed regions and a strictly limited number of developing regions.

Bobillo et al. (2010) examined the association between international diversification and firm performance. Based on a sample of manufacturing firms in five countries as Germany, France, the United Kingdom, Spain, and Denmark, the results showed that the mix of internal and external competitive advantages affected the relation between international diversification and firm performance.

Kahloul and Hallara (2010) studied the relationship between diversification, performance and risk in 69 French large firms between 1995 and 2005. They utilized Entropy Index and Herfindal Index as well as ROA, Tobin's Q, risk, debt and growth. As a result, they found that there is no relationship between diversification and performance. In addition, there is no linear relation between total risk and diversification.

Some scholars did a research in 308 restaurant firms from USA (Park \& Jang, 2011). They utilized Entropy index as corporate diversification and ROA, ROS and risk of profitability as financial performance indicators. They discovered that at a certain level, related diversification declines profitability. On the other hand, at a certain level, unrelated diversification increases profitability. They concluded on the volatility of accounting profitability that at a certain level, related diversification increases volatility and unrelated diversification decreases it. In addition, they found these firms did not profit from a low level of related diversification.

Some others rely on small and medium Spanish manufacturing firms over the years 1993-2006 (Muñoz-Bullón \& Sanchez-Bueno, 2011). They utilize ROA and ROS as dependent variables and corporate diversification (product and international) as independent variable with respect to Size, leverage, liquidity, R\&D and market demand-industry effect as control variables. They reported a negative relationship between geographic expansion and profitability. Therefore, the adoption of both product and international diversification is not associated with higher performance. 
Table 2. Summary of Studies Done on Developed Countries

\begin{tabular}{|c|c|c|c|c|c|c|c|c|c|}
\hline & 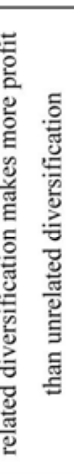 & 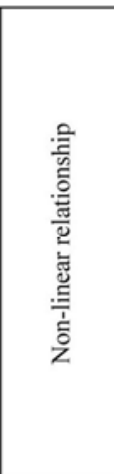 & 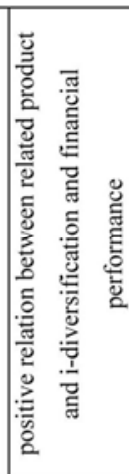 & 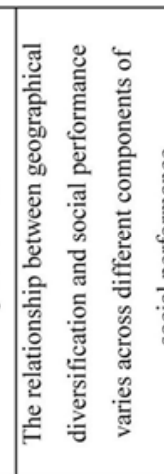 & 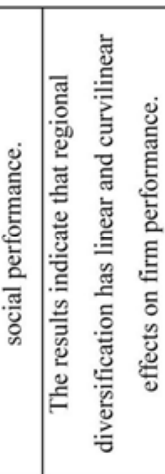 & 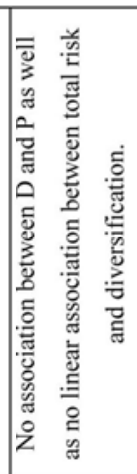 & 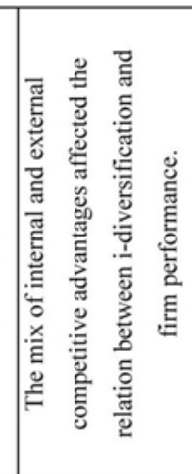 & 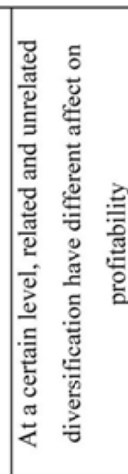 & 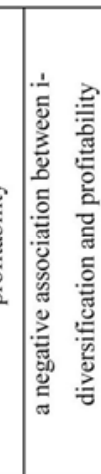 \\
\hline & 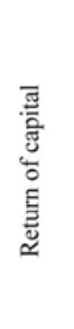 & $\stackrel{\text { q }}{\approx}$ & 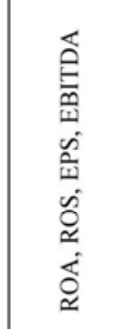 & 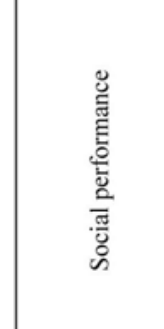 & 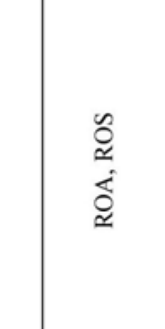 & 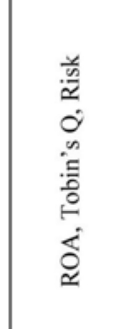 & 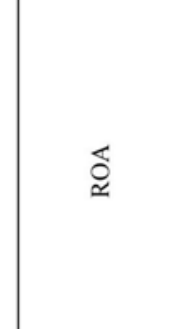 & 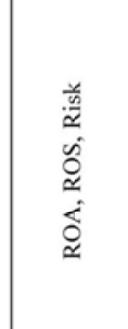 & 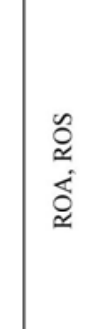 \\
\hline & 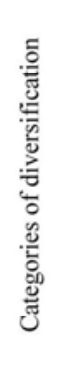 & 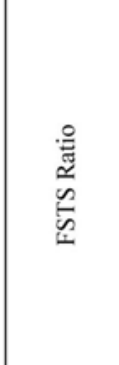 & 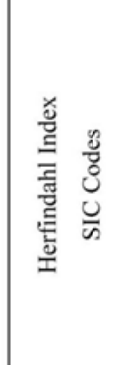 & 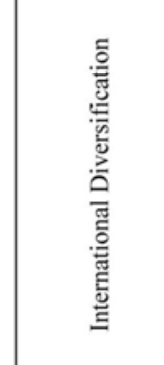 & 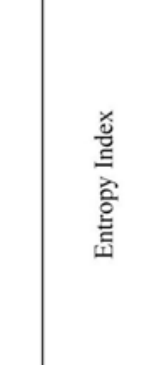 & 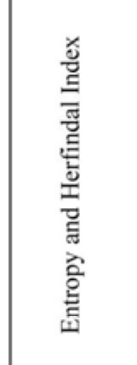 & 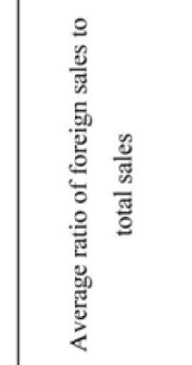 & 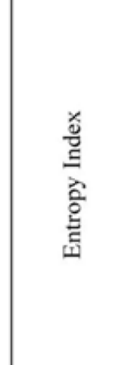 & 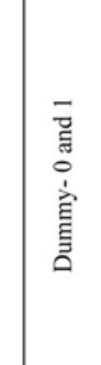 \\
\hline & 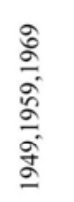 & $\begin{array}{l}\text { बे } \\
\frac{\sigma}{\alpha} \\
\text { a }\end{array}$ & 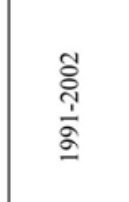 & ఫ్రి & $\begin{array}{l}\text { 密 } \\
\text { s. }\end{array}$ & 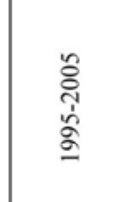 & $\begin{array}{l}\overline{\mathrm{o}} \\
\frac{1}{\sigma a} \\
\stackrel{\sigma}{a}\end{array}$ & 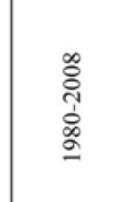 & 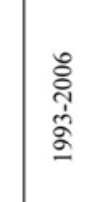 \\
\hline 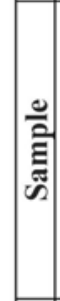 & 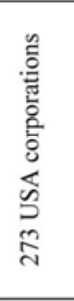 & 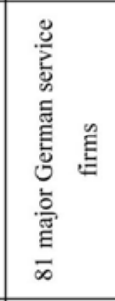 & 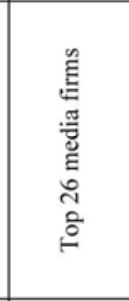 & 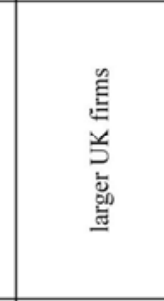 & 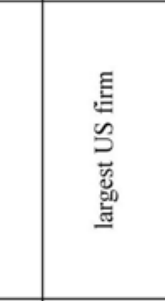 & 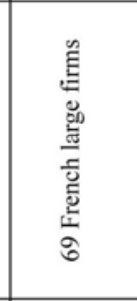 & 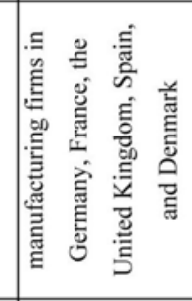 & 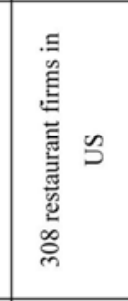 & 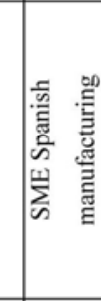 \\
\hline & 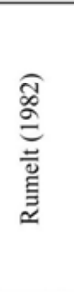 & 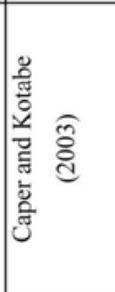 & 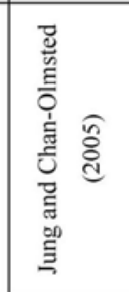 & 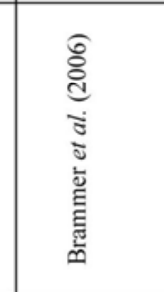 & 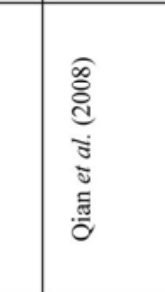 & 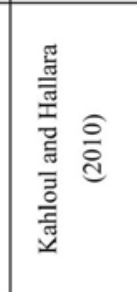 & 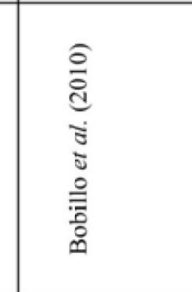 & 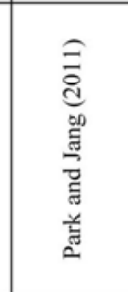 & 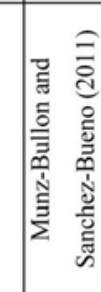 \\
\hline
\end{tabular}




\section{Studies on Developing Countries}

Lins and Servaes (2002) done their studies in one thousand firms from some emerging markets such as Hong Kong, India, Indonesia, Malaysia, Singapore, South Korea, and Thailand in 1995. They found diversified firms less profitable than focusi firms. In addition, they concluded there is a discount for industrial group firms and for diversified firms which has a ten to thirty percent management ownership concentration. Finally, the results did not support internal capital market efficiency in economies with severe capital market imperfections.

Ahmad et al. (2003) started a research on corporate diversification in Malaysia. They investigated the relationship between corporate governance, ownership structure and corporate diversification in Bursa Malaysia. They computed corporate diversification by Herfindahl index and number of segment and found non-institutional blockholding was negatively related with diversification. In addition, they found out there is not a significant relationship between managerial ownership and diversification although the directions were generally as expected. Therefore, they concluded good corporate governance was shown to reduce corporate diversification activities.

Clasessens et al. (2003) have done a research on corporate diversification in South Korea, Japan and seven east Asian countries as Hong Kong, Indonesia, Mallaysia, Philippines, Singapore, Taiwan and Thailand during the years 1991 to 1996. They examined the patterns of vertical relatedness and complementarily in East Asia countries. They investigated the short- and long-term productivity effects associated with the different types of business combination. They found out, except for Japanese firms, vertically integrated firms experience poor performance both in the short- and the long-term. By contrast, firms exploring complementary diversification are generally associated with positive short- and long-term performance.

Some scholars ascertained the relationship between international diversification and financial performance with new classification of financial performance (Tongli, Ping, \& Chiu, 2005). They divided financial performance as accounting-based (ROA), market-based (share price) and value-based (Tobin's Q). In addition, they computed international diversification by Entropy index and considering firm size, age, leverage, risk, industry membership, GNP as control variables. They found out international diversification is positively correlated to performance while product diversification is negatively correlated.

Some researchers found out not only diversification do not reduce the firm value, but also value increases when the level of diversification increases (Ishak \& Napier, 2006). They examined on ownership structures and corporate diversification on 355 Public Listed firms in Malaysia. They showed more than half of the firms analyzed were diversified. However, the results of the research provided no evidence that diversified firms in Malaysia are valued differently from focused firms. The finding was inconsistent with the argument that diversification reduces the value of firms.

Chakrabarti et al. (2007) examined the effect of corporate diversification on performance for 


\section{Macrothink}

some firms acting in stable period and economy shock. They did their research in six Asian countries between 1988 and 2003. They concluded that diversification has a negative effect on performance in more developed institutional environments; although, in least developed environments there is an improving performance. Even though in least developed institutional environments, diversification proposes limited advantages once an economy-wide shock strikes. As a result, they found out that the consequent of diversification is influenced with institutional environments, economic stability and affiliation in business groups.

Other researchers examined diversification and performance of 70 Malaysian firms from years 2001 to 2005 (Daud, Salamudin, \& Ahmad, 2009). Their independent variable was number of segments, the dependent variables were ROA and market measure and the control variables were risk, size, inflation and leverage. They showed firms with focused strategy can achieve high performance and financial ratio is affected by risk and size of firms. In addition, firms at low risk usually get high returns.

Chen and Yu (2011) developed several hypotheses based on the agency theory and tests the relationships among managerial ownership, corporate diversification, and firm performance using a sample of 98 firms listed on the Taiwan Stock Exchange. The results show a U-shaped relationship between managerial ownership and corporate diversification. Moreover, corporate diversification is positively associated with short-term firm performance and bears no relationship with mid-term firm performance, while firms engaged in unrelated diversification outperform those engaged in related diversification. 


\section{A Macrothink}

Table 3. Summary of Studies Done on Developing Countries

\begin{tabular}{|c|c|c|c|c|c|c|c|c|}
\hline 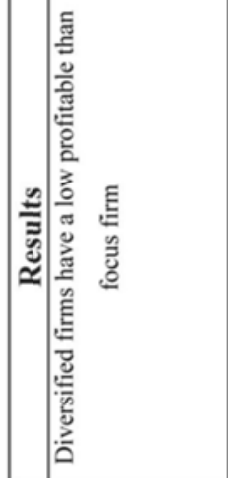 & 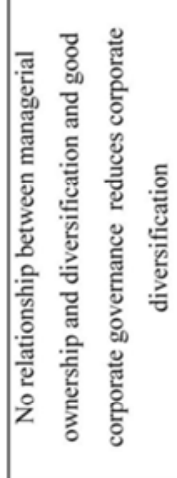 & 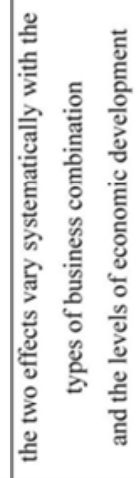 & 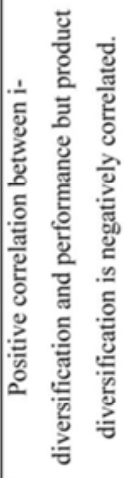 & 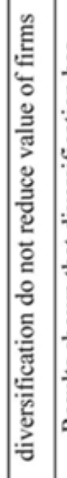 & 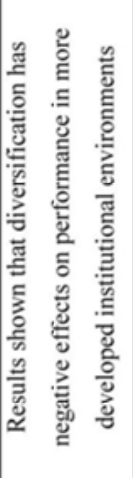 & 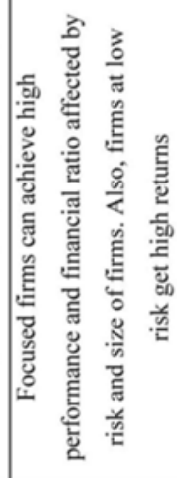 & 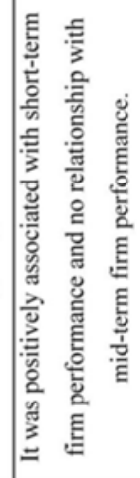 & 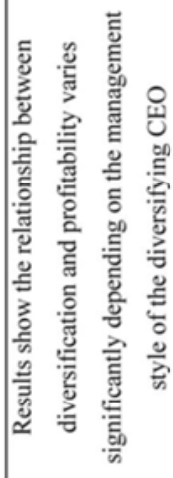 \\
\hline 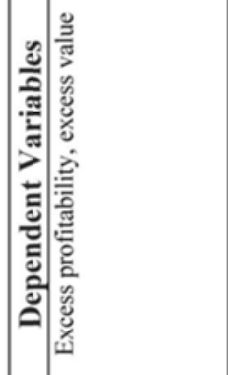 & 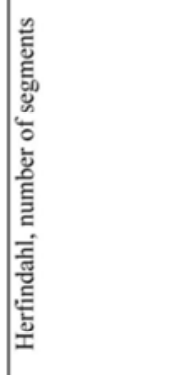 & 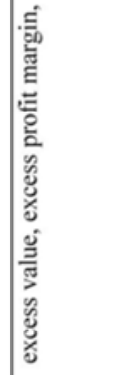 & 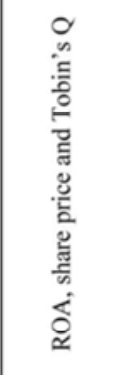 & 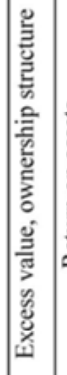 & & 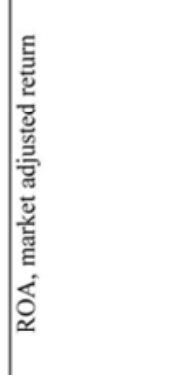 & $\oint_{\approx}$ & 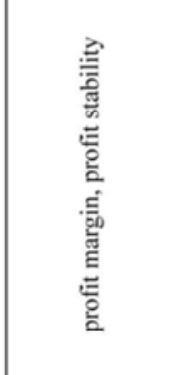 \\
\hline 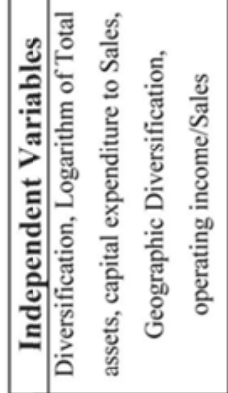 & 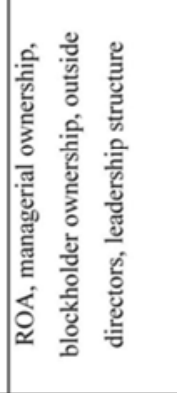 & 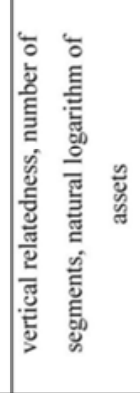 & 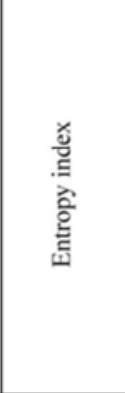 & 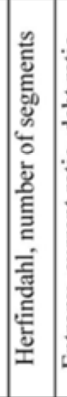 & 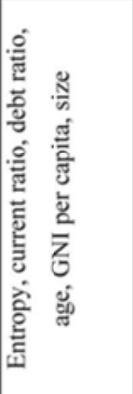 & 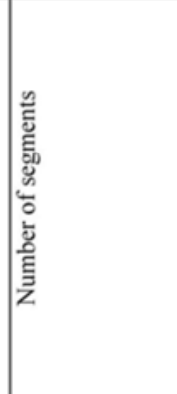 & 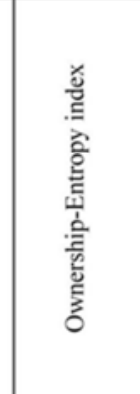 & 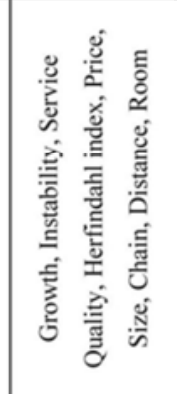 \\
\hline : & 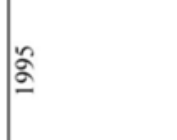 & $\frac{\grave{1}}{\frac{1}{2}}$ & $\begin{array}{l}\text { aे } \\
\text { ড̀े } \\
\text { aे }\end{array}$ & ఫ్సి & ઠి & 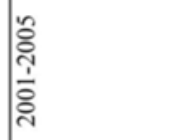 & $\begin{array}{l}\overline{\mathrm{ŏ}} \\
\text { ఏ }\end{array}$ & 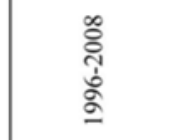 \\
\hline 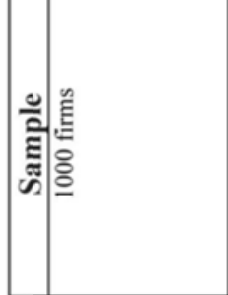 & 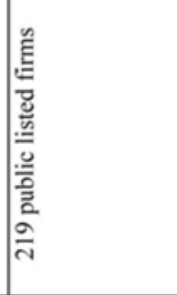 & 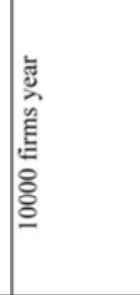 & 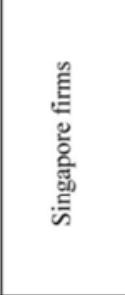 & 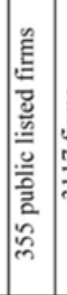 & 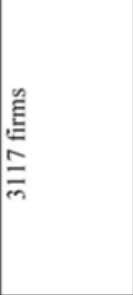 & 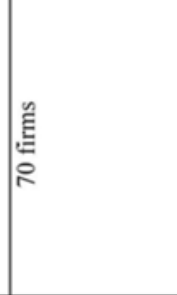 & 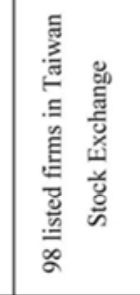 & 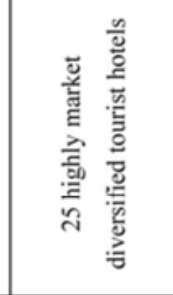 \\
\hline 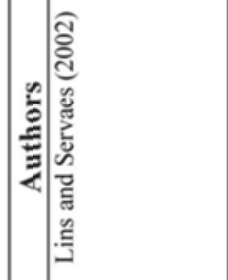 & 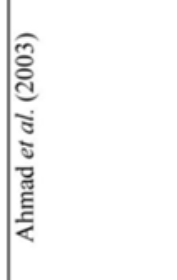 & 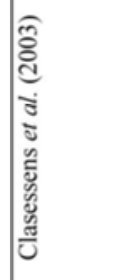 & 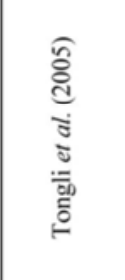 & 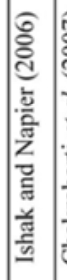 & & 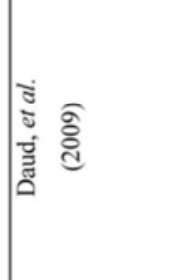 & 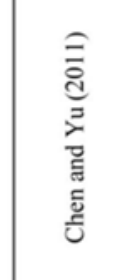 & 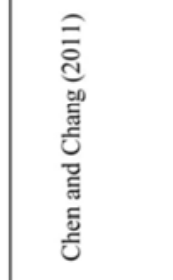 \\
\hline
\end{tabular}




\section{Summary}

As can be seen, the result of studies is contradictory. Some researchers found there is no relationship between diversification and performance (Kahloul \& Hallara, 2010), while others state focus firms outperform than diversified firms (Ibrahim \& Kaka, 2007). Additionally, some scholars found there is a positive relationship between related diversification and financial performance (Benston, 1980; Christensen \& Montgomery, 1981; Palepu, 1985; Richard P. Rumelt, 1982; Scherer, 1980; Steiner, 1975; Teece, 1980); however, some studies show than firm can get profitable by doing unrelated diversification strategy (Park \& Jang, 2011; Scharfstein \& Stein, 2000). On the other hand, some research determines a negative association between product diversification and performance (Chakrabarti, et al., 2007; Claessens, et al., 2003; Daud, et al., 2009; Lang \& Stulz, 1994; Lins \& Servaes, 2002; C. A. Montgomery, 1985; Richard P. Rumelt, 1982; Tongli, et al., 2005). Even though, the positive relationship is seen (Ishak \& Napier, 2006). The other interesting relationship between the two main variables is that some researchers explored nonlinear and inverse U-relationship (Palich, Cardinal, \& Miller, 2000).

Same as product diversification, the impact of international diversification on financial performance is unknown. Some scholars found out positive association (Daniels \& Bracker, 1989; Gomes \& Ramaswamy, 1999; Grant, 1987; Haar, 1989; Kobrin, 1991; Sundaram \& Black, 1992; Tongli, et al., 2005) and negative association (Muñoz-Bullón \& Sanchez-Bueno, 2011; Siddharthan \& Lall, 1982); while, other scholars found out curvilinear relationship between international diversification and performance (Capar \& Kotabe, 2003; Qian, et al., 2008).

As a result, it seems that the studies for association between diversification and financial performance are inconclusive. And scholars should pay more attention to the conditions and environment which other studies done as well as the method and formula which the previous research applied.

\section{Acknowledgments}

The authors would like to thank the Universiti Teknologi Malaysia (UTM). This research has been supported by UTM through International Doctorate Fellowship (IDF).

\section{References}

Ahmad, A. C., Ishak, Z., \& Manaf, N. A. A. (2003). Corporate governance, ownership structure and corporate diversification: Evidence from the Malaysian listed companies. Asian Academy of Management Journal, 8, 67-89.

Amit, R., \& Livnat, J. (1988). Diversification strategies, business cycles and economic performance. Strategic Management Journal, 9(2), 99-110. http://dx.doi.org/10.1002/smj.4250090202

Ansoff, H. I. (1957). Strategies for diversification. Harvard business review, 35(5), 113-124.

Ansoff, H. I. (1965). Corporate strategy: An analytic approach to business policy for growth 
and expansion: McGraw-Hill New York.

Barney, J. B. (2010). Strategic management and competitive advantage: concepts (Third ed.): Prentice hall.

Bartlett, C. A., \& Ghoshal, S. (1999). Managing across borders: The transnational solution (Vol. 2): Taylor \& Francis.

Baysinger, B., \& Hoskisson, R. E. (1989). Diversification strategy and R\&D intensity in multiproduct firms. The Academy of Management Journal, 32(2), 310-332. http://dx.doi.org/10.2307/256364

Benston, G. J. (1980). Conglomerate mergers: Causes, consequences, and remedies: American Enterprise Institute for Public Policy Research.

Berg, N. (1973). Corporate role in diversified companies. Business policy: Teaching and research, 230, 245.

Berg, N., \& Pitts, R. A. (1979). Strategic management: the multi-business corporation. Strategic Management: A New View of Business Policy and Planning. Little, Brown and Co., Boston, MA, 339-348.

Berry, C. H. (1971). Corporate growth and diversification. Journal of Law and Economics, 14(2), 371-383. http://dx.doi.org/10.1086/466714

Bobillo, A. M., López-Iturriaga, F., \& Tejerina-Gaite, F. (2010). Firm performance and international diversification: The internal and external competitive advantages. International Business Review, 19(6), 607-618. http://dx.doi.org/10.1016/j.ibusrev.2010.03.006

Brammer, S. J., Pavelin, S., \& Porter, L. A. (2006). Corporate social performance and geographical diversification. Journal of Business Research, 59(9), 1025-1034. http://dx.doi.org/10.1016/j.jbusres.2006.04.001

Bühner, R. (1987). Assessing international diversification of West German corporations. Strategic Management Journal, 8(1), 25-37. http://dx.doi.org/10.1002/smj.4250080104

Capar, N., \& Kotabe, M. (2003). The relationship between international diversification and performance in service firms. Journal of International Business Studies, 34(4), 345-355. http://dx.doi.org/10.1057/palgrave.jibs.8400036

Caves, R. E. (1981). Diversification and Seller Concentration: Evidence from Changes, 1963-72. The Review of Economics and Statistics, 63(2), 289-293. http://dx.doi.org/10.2307/1924100

Caves, R. E. (2007). Multinational enterprise and economic analysis: Cambridge Univ Pr.

Chakrabarti, A., Singh, K., \& Mahmood, I. (2007). Diversification and performance: evidence from East Asian firms. Strategic Management Journal, 28(2), 101-120. http://dx.doi.org/10.1002/smj.572 
Chatterjee, S., \& Blocher, J. D. (1992). Measurement of firm diversification: is it robust? The Academy of Management Journal, 35(4), 874-888. http://dx.doi.org/10.2307/256320

Chen, C. J., \& Yu, C. M. J. (2011). Managerial ownership, diversification, and firm performance: Evidence from an emerging market. International Business Review.

Chen, C. M., \& Chang, K. L. (2011). Diversification strategy and financial performance in the Taiwanese hotel industry. International Journal of Hospitality Management.

Christensen, H. K., \& Montgomery, C. A. (1981). Corporate economic performance: Diversification strategy versus market structure. Strategic Management Journal, 2(4), 327-343. http://dx.doi.org/10.1002/smj.4250020402

Claessens, S., Djankov, S., Fan, J. P. H., \& Lang, L. H. P. (2003). When does corporate diversification matter to productivity and performance? Evidence from East Asia. Pacific-Basin Finance Journal, 365-392. http://dx.doi.org/10.1016/S0927-538X(03)00029-5

Contractor, F. J., Kundu, S. K., \& Hsu, C. C. (2003). A three-stage theory of international expansion: The link between multinationality and performance in the service sector. Journal of international business studies, 33(1), 48-60.

Daniels, J. D., \& Bracker, J. (1989). Profit performance: Do foreign operations make a difference? Management International Review, 46-56.

Datta, D. K., Rajagopalan, N., \& Rasheed, A. (1991). Diversification and Performance: Critical Review and Future Directions*. Journal of Management Studies, 28(5), 529-558. http://dx.doi.org/10.1111/j.1467-6486.1991.tb00767.x

Daud, W., Salamudin, N., \& Ahmad, I. (2009). Corporate diversification performance. IBEJ, 2(1), 01-18.

Denis, D. J., Denis, D. K., \& Sarin, A. (1999). Agency theory and the influence of equity ownership structure on corporate diversification strategies. Strategic Management Journal, 20(11),

1071-1076. http://dx.doi.org/10.1002/(SICI)1097-0266(199911)20:11<1071::AID-SMJ70>3.0.CO;2-G

Edwards, C. D. (1955). Conglomerate bigness as a source of power: Princeton University Press.

Errunza, V. R., \& Senbet, L. W. (1984). International corporate diversification, market valuation, and size-adjusted evidence. The Journal of Finance, 39(3), 727-743.

Fatemi, A. M. (1984). Shareholder benefits from corporate international diversification. Journal of finance, 1325-1344.

Geringer, J., Tallman, S., \& Olsen, D. (2000). Product and international diversification among Japanese multinational firms. Strategic Management Journal, 21(1), 51-80. http://dx.doi.org/10.1002/(SICI)1097-0266(200001)21:1<51::AID-SMJ77>3.0.CO;2-K 
Geyikdagi, Y. M., \& Geyikdagi, N. Y. (1989). International diversification in Latin America and the industrialized countries. Management International Review, 62-71.

Ghoshal, S. (1987). Global strategy: An organizing framework. Strategic Management Journal, 8(5), 425-440. http://dx.doi.org/10.1002/smj.4250080503

Gomes, L., \& Ramaswamy, K. (1999). An empirical examination of the form of the relationship between multinationality and performance. Journal of international business studies, 173-187. http://dx.doi.org/10.1057/palgrave.jibs.8490065

Grant, R. M. (1987). Multinationality and performance among British manufacturing companies. Journal of international business studies, 79-89. http://dx.doi.org/10.1057/palgrave.jibs.8490413

Haar, J. (1989). A comparative analysis of the profitability performance of the largest US, European and Japanese multinational enterprises. Management International Review, 5-18.

Habib, M. M., \& Victor, B. (1991). Strategy, structure, and performance of US manufacturing and service MNCs: A comparative analysis. Strategic Management Journal, 12(8), 589-606. http://dx.doi.org/10.1002/smj.4250120803

Hamel, G. (1991). Competition for competence and interpartner learning within international strategic alliances. Strategic Management Journal, 12(S1), 83-103. http://dx.doi.org/10.1002/smj.4250120908

Hillebrandt, P., \& Cannon, J. (1990). The modern construction firm: Macmillan.

Hitt, M., \& Ireland, R. (1986). Relationships among corporate level distinctive competencies, diversification strategy, corporate structure and performance. Journal of Management Studies, 23(4), 401-416. http://dx.doi.org/10.1111/j.1467-6486.1986.tb00425.x

Hitt, M. A., Hoskisson, R. E., \& Kim, H. (1997). International diversification: Effects on innovation and firm performance in product-diversified firms. Academy of Management Journal, 767-798. http://dx.doi.org/10.2307/256948

Hitt, M. A., Ireland, R. D., \& Hoskisson, R. E. (2007). Strategic management: Competitiveness and globalization: South-Western Pub.

Hymer, S. H. (1976). The international operations of national firms: A study of direct foreign investment.

Iacobucci, D., \& Rosa, P. (2005). Growth, diversification, and business group formation in entrepreneurial firms. Small Business Economics, 25(1), 65-82. http://dx.doi.org/10.1007/s11187-005-4258-8

Ibrahim, Y., \& Kaka, A. (2007). The impact of diversification on the performance of UK construction firms. Journal of Financial Management of Property and Construction, 12(2), 73-86. http://dx.doi.org/10.1108/13664380780001095 
Ishak, Z., \& Napier, C. (2006). Expropriation of Minority Interests and Corporate Diversification in Malaysia. Asian Academy of Management Journal of Accounting and Finance, 2, 85-113.

Jacquemin, A. P., \& Berry, C. H. (1979). Entropy measure of diversification and corporate growth. The Journal of Industrial Economics, 27(4), 359-369. http://dx.doi.org/10.2307/2097958

Jensen, M. C. (1986). Agency costs of free cash flow, corporate finance, and takeovers. The American Economic Review, 323-329.

Jensen, M. C., \& Meckling, W. H. (1976). Theory of the firm: Managerial behavior, agency costs and ownership structure. Journal of Financial Economics, 3(4), 305-360. http://dx.doi.org/10.1016/0304-405X(76)90026-X

Jung, J., \& Chan-Olmsted, S. M. (2005). Impacts of media conglomerates' dual diversification on financial performance. Journal of Media Economic's, 18(3), 183-202. http://dx.doi.org/10.1207/s15327736me1803_2

Kahloul, I., \& Hallara, S. (2010). The Impact of Diversification on Firm Performance and Risk: An Empirical Evidence. International Research Journal of Finance and Economics, 35.

Kim, W., Hwang, P., \& Burgers, W. (1989). Global diversification strategy and corporate profit performance. Strategic Management Journal, 10(1), 45-57. http://dx.doi.org/10.1002/smj.4250100105

Kim, W. C., Hwang, P., \& Burgers, W. P. (1993). Multinationals' diversification and the risk - return trade - off. Strategic Management Journal, 14(4), 275-286. http://dx.doi.org/10.1002/smj.4250140404

Kim, W. S., \& Lyn, E. O. (1987). Foreign direct investment theories, entry barriers, and reverse investments in US manufacturing industries. Journal of international business studies, 53-66. http://dx.doi.org/10.1057/palgrave.jibs.8490406

Kim, Y. S., \& Mathur, I. (2008). The impact of geographic diversification on firm performance. International Review of Financial Analysis, 17(4), 747-766. http://dx.doi.org/10.1016/j.irfa.2007.09.007

Kobrin, S. J. (1991). An empirical analysis of the determinants of global integration. Strategic Management Journal, 12(S1), 17-31. http://dx.doi.org/10.1002/smj.4250120904

Kogut, B. (1993). Designing global strategies: profiting from operational flexibility'. Readings in International Business, The MIT Press, Cambridge, MA, 195-213.

Kohers, T. (1975). The effect of multinational operations on the cost of equity capital of US corporations: An empirical study. Management International Review, 15(2/3), 121-124.

Kotabe, M., Srinivasan, S. S., \& Aulakh, P. S. (2002). Multinationality and firm performance: The moderating role of $\mathrm{R} \& \mathrm{D}$ and marketing capabilities. Journal of international business 
studies, 79-97. http://dx.doi.org/10.1057/palgrave.jibs.8491006

Lamont, B. T., \& Anderson, C. R. (1985). Mode of corporate diversification and economic performance. Academy of Management Journal, 28(4), 926-934. http://dx.doi.org/10.2307/256245

Lang, L., \& Stulz, R. (1994). Tobin's q, corporate diversification, and firm performance. Journal of political economy, 102(6), 1248-1280. http://dx.doi.org/10.1086/261970

Li, X. (2004). Diversification and Firm Performance: The Case of China. Chinese Business Review, 3(5), 1-8.

Lins, K., \& Servaes, H. (2002). Is corporate diversification beneficial in emerging markets? Financial Management, 31(2), 5-31. http://dx.doi.org/10.2307/3666220

Martin, J. D., \& Sayrak, A. (2003). Corporate diversification and shareholder value: a survey of recent literature. Journal of Corporate Finance, 9(1), 37-57. http://dx.doi.org/10.1016/S0929-1199(01)00053-0

Mat Nor, F. (2003). Malaysian mergers and acquisitions, theory and selected cases. Kuala Lumpur: Prentice Hall.

McConnell, C., Brue, S., \& Flynn, S. (2009). Economics: Principles, Problems and Policies.

McVey, J. S. (1972). The industrial diversification of multi-establishment manufacturing firms: A developmental study. Canadian Statistical Review, 47(4/6), 112-117.

Miller, J. C., \& Pras, B. (1980). The effects of multinational and export diversification on the profit stability of US corporations. Southern Economic Journal, 792-805. http://dx.doi.org/10.2307/1057148

Miller, R. A. (1973). Concentration and marginal concentration, advertising and diversity: Three issues in structure performance tests. Industrial Organization Review, 1(1), 15-24.

Montgomery, C. (1994). Corporate diversification. The Journal of Economic Perspectives, 8(3), 163-178. http://dx.doi.org/10.1257/jep.8.3.163

Montgomery, C. A. (1985). Product-market diversification and market power. Academy of Management Journal, 789-798. http://dx.doi.org/10.2307/256237

Montgomery, C. A., \& Wernerfelt, B. (1988). Diversification, Ricardian rents, and Tobin's q. The RAND Journal of Economics, 623-632. http://dx.doi.org/10.2307/2555461

Morck, R., \& Yeung, B. (1991). Why investors value multinationality. Journal of Business, 165-187. http://dx.doi.org/10.1086/296532

Muñoz-Bullón, F., \& Sanchez-Bueno, M. J. (2011). Is there new evidence to show that product and international diversification influence SMEs' performance? EuroMed Journal of Business, 6(1), 63-76. 
Palepu, K. (1985). Diversification strategy, profit performance and the entropy measure. Strategic Management Journal, 6(3), 239-255. http://dx.doi.org/10.1002/smj.4250060305

Palich, L., Cardinal, L., \& Miller, C. (2000). Curvilinearity in the diversification-performance linkage: An examination of over three decades of research. Strategic Management Journal, 21(2), 155-174. http://dx.doi.org/10.1002/(SICI)1097-0266(200002)21:2<155::AID-SMJ82>3.0.CO;2-2

Pandya, A. M., \& Rao, N. V. (1998). Diversification and firm performance: An empirical evaluation. Journal of Financial and Strategic Decisions, 11(2), 67-81.

Park, K., \& Jang, S. C. S. (2011). Effect of diversification on firm performance: Application of the entropy measure. International Journal of Hospitality Management.

Penrose, E. G. (1959). The theory of the growth of the firm. New York: John Wiley.

Pitts, R. (1976). Diversification strategies and organizational policies of large diversi ed rms. Journal of Economics and Business, 28, 181-188. http://dx.doi.org/10.2307/255394

Pitts, R., \& Hopkins, H. (1982). Firm diversity: Conceptualization and measurement. Academy of Management Review, 7(4), 620-629.

Pitts, R. A. (1977). Strategies and Structures for Diversification. The Academy of Management Journal, 20(2), 197-208.

Qian, G., Li, L., Li, J., \& Qian, Z. (2008). Regional diversification and firm performance. Journal of International Business Studies, 39(2), 197-214. http://dx.doi.org/10.1057/palgrave.jibs.8400346

Rumelt, R. P. (1974). Strategy, structure, and economic performance. Division of Research, Graduate School of Business Administration, Harvard University (Boston and Cambridge, Mass.).

Rumelt, R. P. (1982). Diversification strategy and profitability. Strategic Management Journal, 3, 359-369. http://dx.doi.org/10.1002/smj.4250030407

Santalo, J., \& Becerra, M. (2008). Competition from specialized firms and the diversification-performance linkage. The Journal of Finance, 63(2), 851-883. http://dx.doi.org/10.1111/j.1540-6261.2008.01333.x

Scharfstein, D. S., \& Stein, J. C. (2000). The dark side of internal capital markets: Divisional rent - seeking and inefficient investment. The Journal of Finance, 55(6), 2537-2564. http://dx.doi.org/10.1111/0022-1082.00299

Scherer, F. (1980). Industrial market structure and economic performance.

Shackman, J. D. (2007). Corporate diversification, vertical integration, and internal capital markets: A cross-country study. Management International Review, 47(4), 479-504. http://dx.doi.org/10.1007/s11575-007-0027-z 
Siddharthan, N. S., \& Lall, S. (1982). The recent growth of the largest us multinationals. Oxford Bulletin of Economics and Statistics, 44(1), 1-13. http://dx.doi.org/10.1111/j.1468-0084.1982.mp44001001.x

Steiner, P. O. (1975). Mergers: Motives, effects, policies: University of Michigan Press.

Sullivan, D. (1994a). Measuring the degree of internationalization of a firm. Journal of international business studies, 325-342. http://dx.doi.org/10.1057/palgrave.jibs.8490203

Sullivan, D. (1994b). The" threshold of internationalization:" Replication, extension, and reinterpretation. MIR: Management International Review, 165-186.

Sundaram, A. K., \& Black, J. S. (1992). The environment and internal organization of multinational enterprises. Academy of Management Review, 729-757.

Tallman, S., \& Li, J. (1996). Effects of international diversity and product diversity on the performance of multinational firms. Academy of Management Journal, 179-196. http://dx.doi.org/10.2307/256635

Teece, D. J. (1980). Economies of scope and the scope of the enterprise. Journal of Economic Behavior \& Organization, 1(3), 223-247. http://dx.doi.org/10.1016/0167-2681(80)90002-5

Tongli, L., Ping, E. J., \& Chiu, W. K. C. (2005). International diversification and performance: evidence from Singapore. Asia Pacific Journal of Management, 22(1), 65-88. http://dx.doi.org/10.1007/s10490-005-6418-4

Vernon, R. (1971). Sovereignty at bay: The multinational spread of US enterprises. The International Executive, 13(4), 1-3. http://dx.doi.org/10.1002/tie.5060130401

Wrigley, L. (1970). Divisional autonomy and diversification: Harvard University.

Yip, G. S. (1982). Diversification entry: Internal development versus acquisition. Strategic Management Journal, 3(4), 331-345. http://dx.doi.org/10.1002/smj.4250030405 